\title{
IMPLEMENTASI METODE DRILL MENGGUNAKAN FLASHCARD TERHADAP PERILAKU CUCI TANGAN PADA ANAK TUNARUNGU
}

\author{
Yulifah Salistia Budi ${ }^{1}$, Dias Pungky Retno Nur Dehvi ${ }^{2}$ \\ Program Studi Sarjana Keperawatan STIKES Banyuwangi ${ }^{1}$ \\ yulifahsalistia@gmail.com ${ }^{1}$
}

\begin{abstract}
Barriers to language development in deaf children give rise to various complex impacts that interfere with daily life such as self-care, where the barriers or lack of information have an impact on the behavior of deaf children who are less clean, such as washing hands. The flashcard-based drill method can be used as an alternative health education learning media that can be easily accepted and liked by children. This study aims to determine the effect of the flashcard-based drill method on hand washing behavior in deaf children. The type of research used is Pre-Experimental with a research design of One Group Pre-Post Test Design. The sample of this research is 23 special school students from populations 23 students with total sampling. Data collection used an observation sheet for the stages of hand washing and flashcards for the stages of clean hand washing techniques. Data analysis in this study was for the Shapiro-Wilk normality test and the Wilcoxon test with a significance level of $0.05(5 \%)$. The results showed that before the intervention there were 11 respondents (48\%) with good hand washing behavior, and 52\% with moderate behavior. After the intervention, it was found that all of them had good handwashing behavior 23 respondents (100\%). In the Wilcoxon test, the results of the value of sig (2-tailed) $=0.005<0.05$ level (2-tailed) which means that there is a significant influence between the flashcard-mediated drill method on the handwashing behavior of deaf children. So, health education using the flashcard learning method, it can improve the ability of deaf children to take action, which is hoped that this method children can demonstrate handwashing behavior properly and correctly.
\end{abstract}

Keyword $\quad$ : Deaf, Drill Method, Flashcard, Handwashing

\begin{abstract}
ABSTRAK
Hambatan perkembangan bahasa pada anak tunarungu memunculkan berbagai dampak kompleks yang mengganggu kehidupan sehari-hari seperti perawatan diri (self-care), dimana hambatan atau kurangnya informasi tersebut berdampak pada perilaku anak tunarungu yang kurang bersih seperti mencuci tangan. Metode drill bermedia flashcard dapat dijadikan sebagai salah satu alternatif media pembelajaran pendidikan kesehatan yang dapat dengan mudah diterima dan digemari anak. Penelitian ini bertujuan untuk mengetahui pengaruh antara metode drill bermedia flashcard terhadap perilaku cuci tangan pada anak tunarungu. Jenis penelitian yang digunakan adalah Pra-Eksperimental dengan rancangan penelitian One Group Pra-Post Test Design. Populasi penelitian ini adalah 23 siswa SLB dengan tehnik total sampling didapatkan sampel 23 responden. Pengumpulan data menggunakan lembar observasi tahapan cuci tangan bersih dan flashcard tahapan tehnik cuci tangan bersih. Analisis data pada penelitian ini untuk uji Normalitas Shapiro-Wilk dan uji Wilcoxon test dengan taraf signifikansi 0,05 (5\%). Hasil penelitian menunjukkan bahwa sebelum intervensi didapatkan 11 responden $(48 \%)$ dengan perilaku cuci tangan baik, dan $52 \%$ berperilaku cukup. Setelah intervensi didapatkan seluruhnya memiliki perilaku cuci tangan yang baik berjumlah 23 responden (100\%). Pada uji wilcoxon test dengan hasil nilai sig (2-tailed) $=0,005<0,05$ level (2-tailed) yang artinya terdapat pengaruh yang bermakna antara metode drill bermedia flashcard terhadap perilaku cuci tangan anak tunarungu. Dengan memberikan pendidikan kesehatan menggunakan metode pembelajaran flashcard dapat meningkatkan kemampuan anak tunarungu untuk melakukan tindakan, yang mana harapannya metode ini anak dapat menunjukan perilaku cuci tangan dengan baik dan benar.
\end{abstract}

Kata Kunci : Cuci Tangan, Flashcard, Metode Drill, Tunarungu 


\section{PENDAHULUAN}

Kelainan indera pendengaran (tunarungu) merupakan salah satu kelainan fisik yang dialami oleh anak berkebutuhan khusus (ABK) sehingga penderita ini membutuhkan layanan pendidikan khusus. Hal tersebut perlu dilakukan, karena anak dengan kelainan tersebut mereka juga memiliki kelainan dalam aspek sosial sehingga mereka mengalami kesulitan dalam menyesuaikan perilakunya terhadap lingkungan sekitar. Maka, penyandang tunarungu lebih senang berkumpul dengan komunitasnya yaitu sesama penyandang tunarungu (Solikhatun, 2013). Anak tunarungu pada umumnya memiliki karakteristik secara fisik seperti anak normal. Anak tuna rungu memerlukan media belajar berupa alat peraga untuk memperkaya perbendaharaan bahasa. Alatalat peraga itu antara lain miniatur binatang, miniatur manusia, gambargambar yang relevan, buku perpustakaan yang bergambar dan alat-alat permainan anak (Rahmah, 2018).

Dari hambatan dan kelainan yang dialami oleh penderita tunarungu hal tersebut juga berdampak pada aspek pendidikan, emosi sosial perkembangan intelegensi yang dampak tersebut nantinya akan mengganggu dalam kehidupan sehari-harinya terutama dalam hal perawatan diri (selfcare) (Andayani, 2016). Pada masa pandemi saat ini perawatan diri diperlukan tidak terkecuali pada anak dengan kebutuhan khusus. Infeksi Saluran Pernafasan Atas tau yang biasa disebut ISPA merupakan salah satu penyakit infeksi yang timbul akibat kurangnya perawatan diri, dalam hal ini adalah cuci tangan. ISPA yang tidak ditangani dengan baik akan masuk ke jaringan paru-paru dan menyebabkan pneumonia (Israfil et al., 2014). Dari kondisi tersebut dapat meningkatkan resiko kejadian Covid-19, sehingga seseorang yang mengalai ISPA akan lebih beresiko terjangkit virus ini. Tindakan pencegahan yang dapat dilakukan untuk menekan angka kejadian kasus Covid-19 yaitu dengan perawatan diri salah satunya melalui upaya PHBS (Perilaku Hidup Bersih dan Sehat) dengan penggunaan masker, menutup mulut dan hidung saat bersin maupun batuk, mencuci tangan dengan sabun atau desinfektan yang mengandung setidaknya $60 \%$ alkohol, menghindari kontak dengan orang yang terinfeksi, menjaga jarak dari orang-orang serta menahan diri dari menyentuh mata, hidung dan mulut dengan tangan yang tidak dicuci (Gennaro, F., Pizzol, D., Marotta et al., 2020). Mencuci tangan dengan sabun merupakan salah satu bagian dari perawatan diri yang penting untuk diketahui langkah-langkahnya guna upaya preventif kejadian kasus covid-19.

Edukasi tentang perilaku cuci tangan pakai sabun dapat meningkatkan pengetahuan anak usia Sekolah Dasar terkait cuci tangan yang baik dan benar (Tulak et al., 2020). Untuk mengembangkan ketrampilan perawatan diri pada seseorang dibutuhkan informasi, media dan bimbingan yang tepat. Salah satu faktor yang menentukan keberhasilan dalam proses pembelajaran di sekolah adalah faktor antara guru dengan siswa, serta faktor ketepatan menentukan metode mengajar (Purwanto, 2014). Kartu bergambar merupakan media yang efektif untuk meningkatkan pengetahuan, sikap dan prosedur mencuci tangan pada anak SD (Hasanah et al., 2019). Metode pembelajaran yang cukup efektif untuk anak disabilitas salah satunya adalah metode drill, dimana metode tersebut merupakan salah satu cara mengajar anak melaksanakan kegiatan-kegiatan berupa latihan-latihan, agar anak memiliki ketangkasan atau keterampilan yang lebih baik dari apa yang dipelajari. Ciri khas dari metode ini adalah kegiatan berupa pengulangan yang berkali-kali dari suatu hal yang sama. Metode drill bermedia flashcard dapat dijadikan sebagai salah satu alternatif media pembelajaran pendidikan kesehatan yang dapat dengan mudah diterima dan digemari anak. 
Metode tersebut dapat meningkatkan pengetahuan dan praktik cuci tangan (Andayani, 2016). Metode drill bermedia flashcard pada anak berkebutuhan khusus dapat meningkatkan perbedaan pengetahuan yang signifikan pada skor pre test dan post test (Andayani, 2016). Berdasarkan hal tersebut, maka penelitian ini bertujuan untuk menganalisis pengaruh penggunaan metode drill dengan media flashcard terhadap perilaku cuci tangan pada anak berkebutuhan khusus, spesifik pada tuna rungu.

\section{METODE}

Penelitian ini dilaksanakan pada tanggal 27 Juni sampai 8 Juli 2020, menggunakan metode one group pra-post test design. Hasil post test diambil pada hari ke-12 intervensi. Tehnik sampling yang digunakan adalah total sampling dengan 23 sampel siswa SDLB B Negeri Banyuwangi. Penelitian dilakukan di masa pandemi, dimana pada masa tersebut membatasi anak untuk berangkat ke sekolah (tatap muka) sehingga peneliti memanfaatkan media sosial (melalui WhatsApp dan video call) untuk bisa kontak dengan keluarga (wali murid) dan responden. Pengumpulan data pada responden menggunakan lembar observasi terkait perilaku cuci tangan pada sebelum maupun sesudah metode drill dengan media flashcard.

Instrumen yang digunakan pada penelitian ini adalah lembar observasi terkait 6 tahapan cuci tangan bersih dan flashcard 6 tahapan tehnik cuci tangan bersih. Tehnik pengumpulan data dilakukan berdasarkan lulus uji etik penelitian dari Komisi Etik Penelitian Kesehatan (KEPK) STIKES Banyuwangi nomor 343/KEPK/STIKES-BWI.

Sebelum melakukan penelitian, responden melalui wali murid dimintai persetujuan melalui google form yang dikirimkan. Kemudian setelah medapatkan persetujuan, peneliti mengkaji perilaku cuci tangan responden melalui video call dengan bantuan walinya dimana pada saat tersebut peneliti melakukan observasi terkait tehnik cuci tangan yang dilakukan oleh responden.

Tahap pre test, peneliti mengobservasi cara responden dalam mencuci tangan. Selanjutnya pada tahap intervensi, peneliti mengajarkan tehnik cuci tangan 6 langkah menggunakan media flashcard melalui video call aplikasi WhatsApp. Penilaian hasil observasi perilaku cuci tangan pada responden dilakukan dengan tehnik video call aplikasi WhatsApp, dimana peneliti menghubungi responden melalui wali/orang tua. Tehnik video call disesuaikan dengan langkah pelaksanaan metode drill yaitu pertama fase pemberian latihan dimana peneliti menunjukkan satu persatu kartu berukuran $8 \times 12 \mathrm{~cm}$ bergambar 6 langkah mencuci tangan, yang mana pada setiap kartu menggambarkan satu langkah cuci tangan. Fase kedua adalah pelaksanaan latihan, pada fase ini responden diminta untuk menirukan gerakan yang terdapat pada setiap kartu (flashcard) yang sudah ditunjukkan oleh peneliti pada fase pertama tadi. Fase pertama dan kedua dilakukan oleh peneliti dengan tehnik video call sampai hari ke-12 secara terus menerus, untuk melihat perkembangan responden. Fase ketiga yaitu fase mempertanggungjawabkan latihan dimana oleh peneliti dilakukan pada hari ke-12, disini peneliti melakukan refleksi dari apa yang telah dipelajari bersama responden dan pada tahap ini pula peneliti melakukan periode post test yaitu penilaian lembar observasi mencuci tangan pada setiap langkah yang dilakukan oleh responden.

Analisis data yang digunakan pada penelitian ini yaitu uji statistik Willcoxon dengan $\alpha=0,1$ dengan interpretasi apabila diperoleh nilai sig. (2-tailed), dapat disimpulkan bahwa sig. (2-tailed) $=0,005$ $<0,05$, maka Ho ditolak dan Ha diterima. 
HASIL

Tabel 1 Distribusi Jenis Kelamin dan Usia $(\mathbf{n}=\mathbf{2 3})$

\begin{tabular}{lccc}
\hline \multicolumn{1}{c}{ Indikator } & Frekuensi & $\begin{array}{c}\text { Prosentase } \\
(\boldsymbol{\%})\end{array}$ \\
\hline Jenis & Perempuan & 10 & 43 \\
Kelamin & Laki-Laki & 13 & 57 \\
\multirow{3}{*}{ Usia } & 7 tahun & 3 & 13 \\
& 9 tahun & 3 & 13 \\
& 10 tahun & 2 & 9 \\
& 11 tahun & 3 & 13 \\
& 12 tahun & 3 & 13 \\
& 13 tahun & 5 & 22 \\
& 14 tahun & 4 & 17 \\
\hline
\end{tabular}

Tabel 2 Deskripsi Perilaku Cuci Tangan Sebelum dan Sesudah diberi Intervensi $(\mathbf{n}=\mathbf{2 3})$

\begin{tabular}{ccc}
\hline $\begin{array}{c}\text { Perilaku Cuci } \\
\text { Tangan }\end{array}$ & Frekuensi & $\begin{array}{c}\text { Prosentase } \\
(\%)\end{array}$ \\
\hline Sebelum Intervensi & & \\
Baik & 11 & 48 \\
Cukup & 12 & 52 \\
Kurang & 0 & 0 \\
Sesudah Intervensi & & \\
Baik & 23 & 100 \\
Cukup & 0 & 0 \\
Kurang & 0 & 0 \\
\hline
\end{tabular}

Tabel 3 Uji Wilcoxon Pengaruh Metode Drill Bermedia Flashcard Terhadap Perilaku Cuci Tangan Pada Anak Tunarungu

\begin{tabular}{|c|c|}
\hline \multicolumn{2}{|c|}{ Test Statistics ${ }^{\mathrm{a}}$} \\
\hline & $\begin{array}{c}\text { Post Test - Pre } \\
\text { Test }\end{array}$ \\
\hline $\mathrm{Z}$ & $-2,812^{\mathrm{b}}$ \\
\hline Asymp. Sig. (2-tailed) & 005 \\
\hline
\end{tabular}

Dengan menggunakan uji wilcoxon signed rank test diperoleh nilai sig. (2tailed), sehingga dapat disimpulkan bahwa sig. $(2$-tailed $)=0,005<0,05$, maka Ho ditolak dan $\mathrm{Ha}$ diterima yang berarti terdapat pengaruh yang bermakna antara metode drill bermedia flashcard terhadap perilaku cuci tangan pada anak tunarungu di SDLB B Banyuwangi Tahun 2020.

\section{PEMBAHASAN}

Pada penelitian ini menunjukkan bahwa sebagian besar responden adalah laki-laki yaitu $57 \%$ dengan perilaku cuci tangan responden sebelum intervensi menunjukkan $52 \%$ cukup baik dan $48 \%$ baik. Perilaku manusia merupakan semua kegiatan atau aktivitas manusia, baik yang diamati langsung, maupun yang tidak dapat diamati oleh pihak luar (Notoatmodjo, 2014). Faktor yang mempengaruhi perilaku, dapat berupa genetik atau endogen dan eksogen (Sunaryo, 2004). Faktor endogen/genetik merupakan konsepsi dasar atau modal untuk kelanjutan perkembangan perilaku. Faktor genetik berasal dari dalam diri individu, antara lain : jenis ras, jenis kelamin, perilaku pria atas dasar pertimbangan rasional atau akal sedangkan pada wanita atas dasar emosional. Sifat fisik, perilaku individu akan berbeda-beda sesuai dengan sifat fisiknya. Sifat kepribadian merupakan manifestasi dari kepribadian yang dimiliki sebagai perpaduan dari faktor genetik dengan lingkungan.

Bakat pembawaan merupakan interaksi antara faktor genetik dengan lingkungan serta tergantung adanya kesempatan untuk pengembangan. Intelegensi merupakan kemampuan untuk berpikir dalam mempengaruhi perilaku. Hasil penelitian ini menunjukkan bahwa laki-laki memiliki perilaku cuci tangan yang cukup karena laki-laki mampu berpikir logis atau selalu mengedepankan logika, sedangkan perempuan memiliki perasaan yang lebih lembut sehingga mereka akan saling menguatkan satu sama lain akan kekurangan yang mereka miliki. Faktor dari luar individu atau faktor eksogen, faktor ini juga berpengaruh dalam terbentuknya perilaku individu. Perilaku cuci tangan yang ditunujukkan oleh responden sebelum ada intervensi adalah sebagian besar pada tingkat yang masih cukup hal ini dikarenakan lebih 
banyaknya siswa laki-laki dibandingkan perempuan. Faktor endogen jenis kelamin dan usia berperan terhadap perilaku individu dalam melakukan suatu perbuatan. Hal ini menunjukkan bahwa kematangan usia belum tentu bisa dikatakan dapat menentukan tingkat pengetahuan dan skill praktik cuci tangan khususnya pada anak tunarungu.

Setelah diberikan intervensi terhadap responden menunjukkan bahwa 100\% memiliki perilaku cuci tangan yang baik, dengan kata lain sesuai dengan tehnik mencuci tangan yang baik dan benar sesuai dengan ketentuan WHO untuk dapat membunuh kuman. Perilaku adalah segenap manifestasi hayati individu dalam berinteraksi dengan lingkungan, mulai dari perilaku yang paling nampak sampai yang tidak tampak, dari yang dirasakan sampai paling yang tidak dirasakan (Oktaviana, 2015). Perilaku mencuci tangan dengan air saja tidak cukup, terlebih bila mencuci tangan tidak dibawah air mengalir. Mencuci tangan pakai sabun terbukti efektif dalam membunuh kuman yang menempel di tangan (Rifai et al., 2016). Menurut (Notoatmodjo, 2014), dilihat dari bentuk respon terhadap stimulus, maka perilaku dapat dibedakan menjadi dua, yang pertama bentuk pasif /perilaku tertutup (covert behavior) adalah Respon seseorang terhadap stimulus dalam bentuk terselubung atau tertutup. Respon atau reaksi terhadap stimulus ini masih terbatas pada perhatian, persepsi, pengetahuan atau kesadaran dan sikap yang terjadi pada seseorang yang menerima stimulus tersebut, dan belum dapat diamati secara jelas oleh orang lain. Kedua adalah perilaku terbuka (overt behavior) merupakan respon terhadap stimulus sudah jelas dalam bentuk tindakan atau praktik, yang dengan mudah dapat diamati atau dilihat orang lain.

Pada anak dengan dissabilitas, metode pengajaran yang tepat adalah metode drill, dimana metode drill merupakan suatu metode yang memberi kesempatan kepada siswa untuk berlatih melakukan sesuatu keterampilan tertentu berdasarkan penjelasan atau petunjuk guru. Metode latihan disebut juga metode training, yaitu cara mengajar untuk menanamkan kebiasaan-kebiasaan tertentu, juga sebagai sarana untuk memelihara kebiasaankebiasaan yang baik. Selain itu, metode ini dapat digunakan untuk memperoleh suatu ketangkasan, ketepatan, kesempatan, dan keterampilan (Kastolani, 2014). Tahapan dalam pelaksanaan metode drill yaitu pertama fase pemberian latihan, fase kedua adalah langkah pelaksanaan latihan, dan yang ketiga fase mempertanggungjawabkan latihan (Djamarah et al., 2013). Untuk mendapatkan hasil yang baik metode pembelajaran juga didukung dengan adanya media, salah satu media untuk pendidikan inklusi adalah flashcard. Flashcard atau kartu kilas adalah kartu yang digunakan untuk mengingat dan mengkaji ulang dalam proses belajar. Media ini berupa kartu yang berisi informasi baik berupa gambar, kata, huruf dan lain sebagainya yang tercetak pada kartu tersebut baik pada satu sisi maupun kedua sisinya. Media ini memiliki beberapa kelebihan antara lain: [a] mudah dibawa kemana-mana dengan ukuran yang tidak terlalu besar serta dapat digunakan dimana saja tanpa membutuhkan ruangan yang luas, [b] praktis, karena media ini tidak membutuhkan listrik dalam pemakaiannya. Selain itu guru/pendamping juga tidak perlu memiliki keahlian khusus, [c] mudah diingat, karakteristik media ini adalah menyajikan kartu-kartu dengan pesan pendek sehingga mudah diingat serta [d] menyenangkan, karena dalam penggunaannya berupa permainan yang dapat dilakukan oleh guru dan murid (Zuhriyyah, 2017). Jadi, media flashcard merupakan media yang membantu dalam mengingat dan mengkaji ulang bahan pelajaran seperti: definisi atau istilah, simbol-simbol, ejaan bahasa asing, rumusrumus, dan lain-lain. Metode drill bermedia flashcard berpengaruh dalam 
meningkatkan pengetahuan dan praktik cuci tangan pakai sabun pada anak tunagrahita (Andayani, 2016). Media flashcard dapat diaplikasikan secara visual, karena anak tunarungu lebih mengerti ketika informasi yang dia dapat dengan cara visual. Metode drill yang bersifat pengulangan - pengulangan dapat meningkatkan wawasan dan pengingatan kembali sehingga materi pembelajaran yang disampaikan mudah diterima oleh anak-anak.

Berdasarkan hasil penelitian ini, menunjukkan adanya pengaruh metode drill bermedia flashcard terhadap perilaku cuci tangan pada anak tunarungu, dengan menggunakan uji wilcoxon signed rank test diperoleh nilai sig. (2-tailed), sehingga dapat disimpulkan bahwa sig. (2-tailed $)=$ $0,005<0,05$, maka Ho ditolak dan $\mathrm{Ha}$ diterima yang berarti terdapat pengaruh yang bermakna antara metode drill bermedia flashcard terhadap perilaku cuci tangan pada anak tunarungu di SDLB B Banyuwangi Tahun 2020.

Pelaksanaan pre test dan post test sangat direkomendasikan untuk tenaga pendidik karena dinilai cukup praktis dan efisien dalam meningkatkan hasil belajar peserta didik. Kegiatan pre test bermanfaat untuk mendorong peserta didik lebih aktif dalam belajar. Kegiatan post test untuk mengetahui sampai dimana pencapaian peserta didik terhadap bahan pengajaran (pengetahuan maupun keterampilan) setelah mengikuti kegiatan pembelajaran. Jika hasil post test dibandingkan dengan pre test, maka keduanya berfungsi untuk mengukur sampai sejauh mana keefektifan pelaksanaan program pengajaran (Purwanto, 2012).

Metode Drill bermedia flashcard dapat dijadikan sebagai salah satu alternatif media pembelajaran pendidikan kesehatan yang dapat dengan mudah diterima dan digemari anak. Metode tersebut dapat meningkatkan pengetahuan dan praktik cuci tangan (Andayani, 2016). Media flashcard merupakan salah satu media yang bisa digunakan dan terbukti efektif dalam meningkatkan kemampuan mengenal huruf pada anak tunarungu, dimana tehnik penilaiannya menggunakan fase baseline-1 (pre test), intervensi dan baseline-2 (post test) dan hal tersebut terbukti bahwa terdapat kenaikan kemampuan pada siswa tunarungu dalam mengenal huruf (Racmawati et al., 2016). Pembelajaran media flashcard adalah media pembelajaran dalam bentuk kartu bergambar yang ukurannya sekitar $8 \times 12$ $\mathrm{cm}$. Gambar yang ada pada media ini merupakan rangkaian pesan yang disajikan dengan keterangannya. Mudah dibawa kemana-mana karena ukurannya yang tidak besar dan ringan. Praktis dalam membuat dan menggunakanya, sehingga kapan pun anak didik bisa belajar dengan baik menggunakan media ini. Media flashcard juga gampang diingat karena kartu ini bergambar dan sangat menarik perhatian, memuat huruf atau angka yang simpel, sehingga merangsang otak untuk lebih lama mengingat pesan yang ada. Bahwa keunggulan dari media flashcard adalah membantu kemampuan otak kanan untuk mengingat gambar dan kata - kata sebagai komponennya. Metode drill bagi anak dissabilitas dengan tuna rungu dapat meningkatkan recall anak terhadap materi yang diterima, adanya pengulangan yang dilakukan secara kontinyu membuat anak mudah mengingat secara visual sehingga terekam untuk dilakukan dalam bentuk perilaku. Hasil penelitian (Sutrisno, 2016) menunjukkan bahwa nilai pra tindakan siswa sebelum metode drill diterapkan pada kegiatan keterampilan membuat batako sebesar 55, nilai tersebut lebih rendah dari KKM sebesar 80. Hal ini menandakan bahwa metode drill dapat meningkatkan hasil psikomotor siswa dissabilitas dalam hal ini tunarungu.

\section{KESIMPULAN}

Anak dissabilitas khususnya tuna rungu, mereka dapat menerima ataupun merekam sesuatu hal/pelajaran dengan baik dengan metode pembelajaran yang 
tepat. Metode drill dengan media flashcard merupakan salah satu metode yang efektif untuk meningkatkan perilaku anak tunarungu pada kondisi yang lebih baik.

\section{UCAPAN TERIMAKASIH}

Pada penelitian ini, peneliti mendapatkan dukungan dari berbagai pihak. Dengan ini, peneliti mengucapkan terimakasih pada PPPM dan Komisi Etik Penelitian STIKES Banyuwangi serta pihak SDLB B Negeri Banyuwangi.

\section{DAFTAR PUSTAKA}

Andayani, R. (2016). Metode Drill Bermedia Flash Card Untuk Meningkatkan Pengetahuan Dan Praktik Cuci Tangan Pakai Sabun Pada Anak Tunagrahita. JHE Journal of Health Education, 1(1), 37-43. http://journal.unnes.ac.id/sju/index.ph $\mathrm{p} / \mathrm{jhealthedu/}$

Djamarah, Bahri, S., \& Aswan, Z. (2013). Strategi Belajar Mengajar. Rineka Cipta.

Gennaro, F., Pizzol, D., Marotta, C., Antunes, M., Racalbuto, V., V., \& N., \& Smith, L. (2020). Coronavirus diseases (COVID-19) current status and future perspectives: A narrative review. International Journal of Environmental Research and Public Health, 17(8).

Hasanah, T. M., Majid, Y. A., \& Tirtayanti, S. (2019). Kartu Bergambar Meningkatkan Pengetahuan, Sikap, dan Prosedur Mencuci Tangan Anak Kelas 5 Sekolah Dasar Di SD Muhammadiyah 14 Balayudha Palembang Tahun 2019. Healthcare Nursing Journal, 2(1). https://doi.org/10.35568/healthcare.v2 i1.485

Israfil, Arief, Y. S., \& Ilya Krisnana.
(2014). Analisis Faktor Yang Berhubungan Dengan Kejadian Ispa Pada Balita Berdasarkan Pendekatan Teori Florence Nightingale Di Wilayah Kerja Puskesmas Alak Kota Kupang NTT. Educacion, 2(2), 2130.

Kastolani. (2014). Model Pembelajaran Inovatif. Stain Salatiga Press.

Notoatmodjo, S. (2014). Ilmu Perilaku Kesehatan. Rineka Cipta.

Oktaviana, D. (2015). Hubungan antara konsep diri dan pergaulan teman sebaya dengan perilaku di lingkungan remaja. Universitas Lampung.

Purwanto. (2012). Metodologi Penelitian Kuantitatif untuk Psikologi dan Pendidikan. Pustaka Pelajar Offset.

Purwanto. (2014). Evaluasi Hasil Belajar. Pustaka Pelajar.

Racmawati, R., Hernawati, T., \& Juhanaini. (2016). Efektifitas Flash Card Dalam Meningkatkan Kemampuan Mengenal Huruf Pada Siswa Tunarungu Kelas Tk-a2 Di Slb Negeri Cicendo Kota Bandung. Jassi Anakku, 17(1), 1-7.

Rahmah, F. N. (2018). Problematika Anak Tunarungu Dan Cara Mengatasinya. Quality, 6(1), 1. https://doi.org/10.21043/quality.v6i1. 5744

Rifai, R., Wahab, A., \& Prabandari, Y. S. (2016). Kebiasaan cuci tangan ibu dan kejadian diare anak: studi di Kutai Kartanegara. Berita Kedokteran Masyarakat, 32(11), 409-414.

Solikhatun, Y. U. (2013). Penyesuaian Sosial pada Penyandang Tunarungu di SLB Negeri Semarang. Educational Psychology Journal, 2(1), 65-72. 
Sunaryo. (2004). Psikologi Untuk Keperawatan. EGC.

Sutrisno, K. T. (2016). Peningkatan Keterampilan Membuat Batako Melalui Metode Drill Bagi Tunagrahita Kategori Sedang Kelas Viii Smplb C1 Di Slb N 1 Sleman. Universitas Negeri Yogyakarta.

Tulak, G. T., Ramadhan, S., \& Musrifah, A. (2020). Edukasi Perilaku Cuci Tangan Pakai Sabun Pada Siswa Untuk Pencegahan Transmisi Penyakit. JMM (Jurnal Masyarakat
Mandiri), 4(1), 37. https://doi.org/10.31764/jmm.v4i1.17 02

Zuhriyyah, A. (2017). Pengembangan Media Pembelajaran Flash Card IPA Pada Anak Tunarungu Kelas VII SMPLB. 